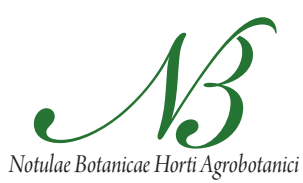

Cluj-Napoca

\title{
Effects of Volatile Emissions of Picea abies Fresh Debris on Ips duplicatus Response to Characteristic Synthetic Pheromone
}

\author{
Mihai-Leonard DUDUMAN ${ }^{1}$, Iuliana VASIAN ${ }^{2}$ \\ 1 "Ştefan cel Mare” University of Suceava, Faculty of Forestry, 13 Universităţii Street, Suceava, Romania; mduduman@usv.ro \\ 2 "Babeş Bolyai" University of Cluj Napoca, "Raluca Ripan" Institute of Chemistry Research, \\ 30 Fântânele Street, Cluj Napoca, Romania; iulianavasian@yahoo.com
}

\begin{abstract}
Ips duplicatus is an important pest of Norway spruce (Picea abies) planted outside of its natural range. This species uses olfactory signals to identify the spruce trees favourable for colonisation. The knowledge of the beetles' response to these stimuli is important for managing this pest. Therefore, the response of Ips duplicatus to a specific synthetic pheromone was investigated under some natural sources of volatile emissions characteristic of Norway spruce. The pheromone traps were installed in two types of forests: one with fresh and large Norway spruce stumps and piles of branches, releasing large amounts of host volatile substances (terpenes and alcohols) and one without such fresh material. The experiment was repeated in three pairs of sites located in plantations out of the natural range of Norway spruce. Finally it was found that Ips duplicatus beetles, regardless of sex, have been concentrated in areas where large amounts of fresh material were available, confirming that Ips duplicatus beetles are using both natural pheromones and specific host volatiles as olfactory stimuli in searching for breeding material.
\end{abstract}

Keywords: Ips duplicatus, natural host volatiles, spruce, synthetic pheromone

\section{Introduction}

The northern bark beetle Ips duplicatus (Sahlberg), (Coleoptera: Curculionidae, Scolytinae) is a common species in the conifer forests from Boreal Eurasia, extending its range during the twentieth century in the Central and South East Europe, where it is considered an invasive species (DAISIE, 2009; Pfeffer, 1995; Sauvard et al., 2010; Turcani et al., 2001; Zúbrik et al., 2006). In Romania, this species is present in most of the Norway spruce area growing at less than $1000 \mathrm{~m}$ altitude a.s.l. (Duduman $e t$ al., 2011), producing outbreaks only in Norway spruce plantations installed outside the natural range, in the North-Eastern part of the country, where, in 2009, killed about 14,000 spruce trees (between 30 and 50 years old) (Olenici et al., 2009, 2011).

Like other bark beetles species, I. duplicatus identifies the already attacked trees through a series of stimuli, an important role being played by olfactory sense. Among these stimuli, the aggregative pheromones play an essential role in coordinating the beetle attack against the host tree (Blomquist et al., 2010; Rudinsky, 1962; Wood, 1982). Nevertheless the spectrum and the quantity of volatiles released by the hosts (terpenes and alcohols) have a special importance in finding new host trees. This was already demonstrated for Ips typographus, where the monotherpenes (with other volatile) released by the Norway spruce trees are important olfactory signals for the beetles, before colonizing new trees (Baier et al., 1999; Byers et al.,
2000; Rudinsky et al., 1971). These conclusions were also confirmed in two studies carried out on the behaviour of Dendroctonus rufipennus (Moeck, 1978) and I. typographus (Austara et al., 1986) in areas with fresh stumps and branch piles.

The present study tried to find out if the I. duplicatus beetles behave as most bark beetle species do. The initial assumption was that $I$. duplicatus would concentrate more in areas were a great quantity of host volatiles being released by large amounts of fresh wood debris.

\section{Materials and methods}

The field tests of $I$. duplicatus response to synthetic aggregative pheromones were carried out in the North-Eastern part of Romania, in three Norway spruce plantations (Zamostea, Calafindeşti and Feteşti) outside of the species natural range. Plantations are under administration of Pătrăuți and Adâncata forest districts (subunits of the Suceava County Branch of the National Forest Administration Romsilva). The stands with similar characteristics (Tab. 1) have strong populations of this bark beetle species, which attacked and killed many of the spruce trees of the foci developed. In each location two experimental plots were installed: one nearby a stand edge recently created after a clear-cutting in January-March 2011, with large and similar amounts of fresh host material (branches, stumps etc.), and another at an old stand edge, without any fresh spruce debris, so with minimal sources of host 
Tab. 1. Location and the main characteristics of the experimental plots

\begin{tabular}{|c|c|c|c|c|c|c|c|c|c|}
\hline No & $\begin{array}{l}\text { Experimental } \\
\text { plots }\end{array}$ & $\begin{array}{l}\text { Abre- } \\
\text { viation }\end{array}$ & Forest district & P.U." & m.c." & Coordinates & Elevation $(\mathrm{m})$ & $\begin{array}{l}\text { Age } \\
\text { (years) }\end{array}$ & $\begin{array}{c}\text { Fresh host } \\
\text { material }\end{array}$ \\
\hline 1 & Zamostea 1 & $\mathrm{Z1}$ & Adâncata & VIII & $3 \mathrm{~B}$ & $\begin{array}{l}47^{\circ} 52^{\prime} 52.02^{\prime \prime} \mathrm{N} \\
26^{\circ} 08^{\prime} 32.46^{\prime \prime} \mathrm{E}\end{array}$ & 375 & 40 & Present \\
\hline 2 & Zamostea 2 & $\mathrm{Z} 2$ & Adâncata & VIII & $4 \mathrm{~A}$ & $\begin{array}{l}47^{\circ} 53^{\prime} 11.04^{\prime \prime} \mathrm{N} \\
26^{\circ} 08^{\prime} 43.49^{\prime \prime} \mathrm{E}\end{array}$ & 335 & 40 & Not present \\
\hline 3 & Calafindești 3 & C3 & Pătrăuți & III & $22 \mathrm{~A}$ & $\begin{array}{l}47^{\circ} 50^{\prime} 59.57^{\prime \prime} \mathrm{N} \\
26^{\circ} 08^{\prime} 36.87^{\prime \prime} \mathrm{E}\end{array}$ & 490 & 40 & Present \\
\hline 4 & Calafindeşti 4 & $\mathrm{C} 4$ & Pătrăuți & III & $22 \mathrm{~A}$ & $\begin{array}{l}47^{\circ} 51^{\prime} 03.09^{\prime \prime} \mathrm{N} \\
26^{\circ} 08^{\prime} 50.16^{\prime \prime} \mathrm{E}\end{array}$ & 496 & 40 & Not present \\
\hline 5 & Fetești 5 & F5 & Adâncata & VI & $36 \mathrm{~A}$ & $\begin{array}{l}47^{\circ} 43^{\prime} 05.03^{\prime \prime} \mathrm{N} \\
26^{\circ} 19^{\prime} 27.95^{\prime \prime} \mathrm{E}\end{array}$ & 400 & 40 & Present \\
\hline 6 & Fetești 6 & F6 & Adâncata & VI & $61 \mathrm{~B}$ & $\begin{array}{l}47^{\circ} 43^{\prime} 32.74^{\prime \prime} \mathrm{N} \\
26^{\circ} 21^{\prime} 02.66^{\prime \prime} \mathrm{E}\end{array}$ & 350 & 40 & Not present \\
\hline
\end{tabular}

Note: "P.U. - production unit; " m.c. - management compartment

volatiles, considered control plot. The two types of surface were treated as experimental replicates.

In each experimental plot, five pheromone traps were installed, at $15 \mathrm{~m}$ one from another and at $10-12 \mathrm{~m}$ from the forest edge. In Z1, Z2, F5 and F6 experimental plots the Intercept ${ }^{\circ}$ wing-type traps were installed. In area C3 and $\mathrm{C} 4$ there were used Theysohn type traps. The traps were baited with synthetic pheromone specific for I. duplicatus. The experiment was conducted between 16 May and 15 June 2011 and the trap catches were collected periodically, after 6-9 days. In each location the temperature was monitored during the experiment with field sensor data logger (Hobo U23-001, USA).

The synthetic pheromone used is based on the distinctive components of the natural aggregation pheromone of I. duplicatus: ipsdienol (Id) and E-myrcenol (EM) (Bakke, 1975; Byers et al., 1990). Equal shares of these two components are considered optimal for the European populations of this bark beetle (Schlyter et al., 2001). To obtain the synthetic pheromone, these components were dissolved in metylbuthenol (MB), which is olfactory indifferent for I. duplicatus. The ratio used for the combination was: $1 \mathrm{Id} / 1 \mathrm{EM} / 33 \mathrm{MB}$. To prevent oxidation of this compound, Buthylated hidroxytoluene (BHT) antioxidant was added: $2.5 \mathrm{~g}$ per $100 \mathrm{ml}$ of pheromones, as prescribed by Erbilgin et al. (2007). Different producers supplied the chemical components used in the experimental field, as shown in Tab. 2.

Tab. 2. Characteristics of chemical compounds used to synthetic pheromones

\begin{tabular}{ccc}
\hline Compound & Purity & Supplier \\
\hline Ipsdienol Racemic (Id) & $\geq 93 \%$ & Bedoukian Research inc., USA \\
E-myrcenol (EM) & $\geq 95 \%$ & $\begin{array}{c}\text { Raluca Ripan” Institute for } \\
\text { Research Chemistry, Romania }\end{array}$ \\
$\begin{array}{c}\text { Methilbuthenol (MB) } \\
\text { Buthylated }\end{array}$ & $\geq 98 \%$ & Sigma Aldrich GmbH, Germany \\
hidroxytoluene (BHT) & $\geq 99 \%$ & Sigma Aldrich GmbH, Germany \\
\hline
\end{tabular}

The dispensers $(50 \times 70 \mathrm{~mm}$ envelopes $)$ used to release of the pheromone were made from low-density polyethylene film of $50 \mu \mathrm{m}$. Each envelope has contained a 55 $\times 40 \mathrm{~mm}$ cellulose support for the pheromone mixture; both the polyethylene film and the cellulose support were provided by "Raluca Ripan" Institute of Chemistry Cluj Napoca. The dispensers were injected with $3.5 \mathrm{ml}$ of pheromones mixture. The released rate was determined in standard condition $\left(20^{\circ} \mathrm{C}, \mathrm{RH} 50 \%\right)$ provided in a climatic chamber (Conviron G30, Canada); after 10 days of testing the average release rate of the pheromonal mixture, for 10 dispensers, was $23.2 \pm 0.4 \mathrm{mg} /$ day.

The analysis of the biological captures was done in laboratory conditions; all I. duplicatus beetles were sexed when catches were less than 50 beetles/trap. For larger captures, the beetles were sexed in groups of 50 randomly chosen individuals according to the same procedure used by Lobinger (1996), Erbilgin et al. (2007) and Blaženec and Jakuš (2009) for I. typographus. The sexes were identified by analysing the genital armature of the adult after dissection.

The data collected from field catches were analysed by ANOVA, looking for the differences between the experimental variants and trying to detect the interaction between experimental trials and the sex of insects. The hypothesis of normal distribution, required by the ANOVA tests, was checked for each distribution, using the ShapiroWilk test. The significance of differences between average values was tested using the Tukey test (Zar, 2010); all statistical computations were done using XLSTAT-Pro 7.5 software, plugged into MS Excel.

\section{Results}

Throughout the field experiment, recorded daily maximum air temperatures in all locations (Fig. 1) were frequently over $16,5^{\circ} \mathrm{C}$, value considered as the minimum threshold for flight of I. typographus (Lobinger, 1994). Therefore, as seasonal activity of both beetle species is 
310
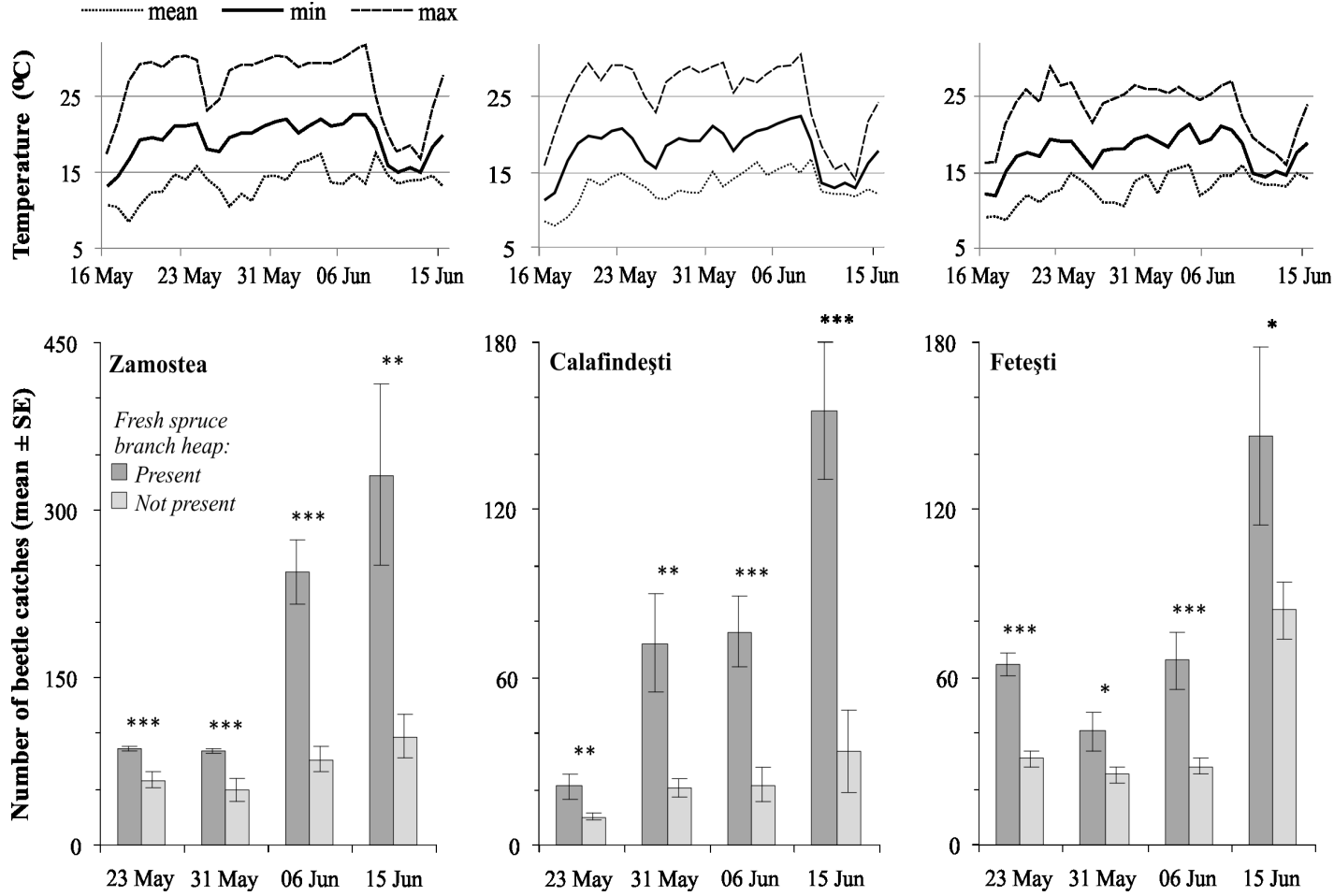

Fig. 1. The response of the $I$. duplicatus beetles to the specific synthetic pheromone in areas with fresh host material comparing to the areas without host material. The air temperature conditions throughout the duration of the experiment

Note: On the top of bars pairs the stars symbolize the significance of differences between averages for the three exceeding likelihood $p<0.05^{*}$ ) significant; $p<0.01^{* *}$ ) distinct significant; $p<0.001^{* * *}$ ) very significant

identical (Holuša et al., 2003), the recorded air temperatures could be considered favourable for I. duplicatus flight activity.

Thus, during the whole experimental trials 9613 beetles of $I$. duplicatus were captured (3615 males and 5998 females). Out of the total, 6947 beetles were captured in experimental plots with fresh spruce material and 2666 beetles were captured in pairwise control plots. The proportion of males was $37.6 \%$ on average, ranging from $35.8 \%$ to $42.2 \%$. In addition to I. duplicatus, some other beetles were captured, as well: I. typographus ( 55 indiv.), Pityogenes chalcographus (142 indiv.), Polygraphus poligraphus (7 indiv.), Dryocoetes sp. (18 indiv.), Hylastes sp. (23 indiv.), Rhagium sp. (9 indiv.).

Tab. 3. Total of Ips duplicatus captures collected in experimental plots

\begin{tabular}{ccccc}
\hline \multirow{2}{*}{ Location } & \multirow{2}{*}{ Exp. plot } & \multirow{2}{*}{$\begin{array}{c}\text { Number } \\
\text { of beetles }\end{array}$} & \multicolumn{2}{c}{ Of which males } \\
\cline { 4 - 5 } & & No. of beetles & $\%$ \\
\hline \multirow{2}{*}{ Zamostea } & Z1 & 3732 & 1335 & 35,8 \\
& Z2 & 1400 & 519 & 37,1 \\
\hline \multirow{2}{*}{ Calafindești } & $\mathrm{C} 3$ & 1626 & 686 & 42,2 \\
& $\mathrm{C} 4$ & 427 & 165 & 38,7 \\
\hline \multirow{2}{*}{ Feteşti } & $\mathrm{C} 5$ & 1589 & 603 & 37,9 \\
& $\mathrm{C} 6$ & 839 & 307 & 36,6 \\
\hline
\end{tabular}

Analyzing the pairs of pilot areas, the most I. duplicatus pieces were captured at Zamostea ( 5132 beetles), followed by Feteşti ( 2428 beetles) and Calafindeşti (2053 beetles) (Tab. 3). The catches recorded was double at Zamostea comparing to other locations and this situation is justified by the large population of $I$. duplicatus already present there, reaching epidemic levels (Duduman et al., 2011).

Concerning the response of I. duplicatus to synthetic pheromones in the two experimental plots, it was found that, regardless of location and time, significantly more beetles were captured in traps installed in areas with wooden debris (Fig. 1), while the interaction between experimental plots and the sex of captured beetles was nonsignificant (Tab. 4). The catches recorded in the area with wooden debris were much higher: from 1.5 times higher (Zamostea, May 16-23) up to cca. 4.6 times (Calafindeşti, June 6-15) comparing to the plots without fresh wooden debris (i.e. the control plots).

The lowest differences between the catches in the two experimental plots were registered in Feteşti, where the wooden debris contribution to larger catches ranged from 1.6 to 2.3 times. These figures do not hold for the other two areas where the differences ranged from 1.5 to 3.4 times at Zamostea and 2.1 to 4.6 times at Calafindeşti.

Analysing the captures in terms of male proportion, large differences in all plots were found among different 
Tab. 4. Outcome of controlled factor and combination of controlled factor and sex on the Ips duplicatus captures

\begin{tabular}{cccccccc}
\hline \multirow{2}{*}{$\begin{array}{c}\text { Experimental } \\
\text { period }\end{array}$} & Statistical value & \multicolumn{5}{c}{ Experimental area } \\
\cline { 3 - 8 } & & \multicolumn{2}{c}{ Zamostea } & \multicolumn{2}{c}{ Calafindeşti } & \multicolumn{2}{c}{ Feteşti } \\
\cline { 3 - 8 } & & Fisher's $\mathrm{P}$ & $\mathrm{P}$ & Fisher's $\mathrm{F}$ & $\mathrm{P}$ & Fisher's F & $\mathrm{P}$ \\
\hline \multirow{2}{*}{ 16-23 May } & Controlled factor & 17,514 & 0,001 & 9,748 & 0,007 & 40,001 & $<0,001$ \\
& Controlled factor x sex & 0,018 & 0,894 & 0,119 & 0,734 & 0,747 & 0,400 \\
\hline \multirow{2}{*}{ 23-31 May } & Controlled factor & 21,808 & $<0,001$ & 13,917 & 0,002 & 7,780 & 0,013 \\
& Controlled factor x sex & 0,629 & 0,439 & 2,443 & 0,138 & 0,018 & 0,896 \\
\hline \multirow{2}{*}{ 31 May-06 Jun. } & Controlled factor & 56,306 & $<0,001$ & 28,830 & $<0,001$ & 21,138 & $<0,001$ \\
& Controlled factor x sex & 2,265 & 0,152 & 2,674 & 0,122 & 2,948 & 0,105 \\
\hline \multirow{2}{*}{ 06-15 Jun. } & Controlled factor & 11,834 & 0,003 & 28,745 & $<0,001$ & 6,628 & 0,020 \\
& Controlled factor x sex & 2,114 & 0,165 & 2,678 & 0,121 & 0,871 & 0,365 \\
\hline
\end{tabular}

Tab. 5. The proportion of males from captures

\begin{tabular}{cccccc}
\hline \multirow{2}{*}{ Location } & \multirow{2}{*}{ Experimental plot } & \multicolumn{4}{c}{ Experimental period / (\%) (mean \pm SE) } \\
\cline { 3 - 6 } & & 16-23 May & $23-31$ May & 31 May-06 Jun. & 06-15 Jun. \\
\hline \multirow{2}{*}{ Zamostea } & Z1 & $55.2 \pm 2.7$ & $51.1 \pm 1.5$ & $39.3 \pm 0.7$ & $24.4 \pm 3.4$ \\
& Z2 & $55.4 \pm 1.3$ & $51.7 \pm 1.0$ & $38.6 \pm 1.0$ & $25.5 \pm 4.4$ \\
\hline \multirow{2}{*}{ Calafindești } & C3 & $54.0 \pm 3.6$ & $47.7 \pm 3.1$ & $30.4 \pm 2.0$ & $25.7 \pm 4.2$ \\
& C4 & $50.4 \pm 3.3$ & $50.9 \pm 1.9$ & $28.8 \pm 1.4$ & $26.3 \pm 1.1$ \\
\hline \multirow{2}{*}{ Feteşti } & F5 & $54.9 \pm 3.7$ & $45.8 \pm 1.4$ & $33.6 \pm 1.2$ & $26.8 \pm 2.0$ \\
& F6 & $55.4 \pm 2.9$ & $46.6 \pm 3.2$ & $33.5 \pm 1.9$ & $27.2 \pm 2.7$ \\
\hline
\end{tabular}

periods along the season, (Tab. 5). However, no significant differences between the male proportions from the captures obtained from the same period in the two experimental variants were observed.

\section{Discussion}

The significantly larger number of $I$. duplicatus beetles captured in areas with fresh host material confirms that the presence of a larger quantity of natural volatile substances characteristically to the spruce (released by the fresh host material) contributes to the increase of the beetles' population in these areas due to insect attraction by these volatiles. This aspect was demonstrated for I. typographus by Bakke (1985), who collected larger captures at traps baited with synthetic pheromone installed along the fresh edge of Norway spruce stands, than those collected at the traps installed on edges of three years old. One year later Austara et al. (1986) captured about 1.7 more beetles at the pheromonal traps installed on the fresh host materials than the beetles captured in plots installed on areas without such fresh materials.

Larger differences within the three pairs of plots from one experimental period to the next one are probably explained by a larger spectrum of the natural volatile substances, released by the host material. It is known that for I. typographus, the terpene with a high concentration (especially of alpha pinene) can be a good repellent (Chararas, 1959; Martin et al., 2002), even when these are combined with specific synthetic pheromones (Olenici et al., 2007). Such situation can be always found after harvesting a large number of trees, when the emissions of terpene are very high, but the alcohols are effectively inexistent (Hietz et al., 2005). On the other hand, once the fresh host material has been decomposed, it releases a great deal of ethanol produced by fermentation process (Hietz et al., 2005) and alcohol vapours have the same synergetic effect as natural terpenes on alluring different bark beetles species (Moeck, 1970; Phillips et al., 1988; Schroeder and Lindelöw, 1989). Yet, these larger amplitudes of the differences between beetles captures couldn't be caused by air temperature, which was quite constant (Fig. 1).

As expected, the I. duplicatus bark beetles are directed not only by aggregative pheromones but also by natural volatiles to identify their next host. The spectrum of volatiles released by fresh Norway spruce debris is somewhat similar to spectrum of volatile substances released by debilitated trees, which are actually chosen for colonization. This explains also the interest in studying these species, more and more frequent in forest areas where large quantities of natural host volatiles might occur, due to various reasons.

Equal proportions of males and females in the catches from the two types of experimental plots show that both females and males of $I$. duplicatus are equally attracted by the natural host volatiles. The reduction of I. duplicatus males number catches as July is approaching is in line with similar observations reported about the captured dynamics of other species of Ips (I. typographus), where the maximum percentage of male specimens are caught at the beginning of flight, in May (Faccoli and Buffo, 2004). This aspect highlights the process of decreasing the number of males in flight, because the males are initiating the early stages of tree colonisation (in the case of I. duplicatus 
312

males are the ones who initiate the attack), when many of them are drowned in the resin released by the tree. The male number can grow up again in the second half of June when the new generation occurs.

\section{Conclusions}

Catches of $I$. duplicatus bark beetle into traps baited with synthetic specific aggregative pheromone are significantly higher in experimental plots where fresh spruce debris are on the site, than the number of catches found in the control plots, without wooden debris. It can be concluded therefore that I. duplicatus in addition of pheromones is using the volatile substances characteristics to spruce trees to locate areas where trees are predisposed to attack.

\section{Acknowledgement}

This work was financed by „The National Authority for Scientific Research" CNCSIS-UEFISCSU, project number PN II-RU 576/2010, contract number 204/2010 and MOTIVE Project-Models for Adaptive Forest Management, funded by $7^{\text {th }}$ EU Framework Programme. The support in the field from the personnel of Suceava County Branch of the National Forest Administration Romsilva (Forest Districts Pătrăuți and Adâncata) is greatly appreciated.

\section{References}

Austara O, Bakke A, Midtgaard F (1986). Response in Ips typographus to logging waste odours and synthetic pheromones. Zeitschrift fur Angewantdte Entomologie 101:194-198

Baier P, Bader R, Rosner S (1999). Monoterpene content and monoterpene emission of Norway spruce (Pices abies L. Karst.) bark in relation to primary attraction of bark beetles (Col. Scolytidae), p. 249-259. In: Lieutier F, Mattson WJ, Wagner MR (Eds.). Physiology and Genetics of TreePhytophage Interactions. Int. Symposium Gujan (France). Les Colloques de l'INRA.

Bakke A (1975). Aggregation pheromone in the bark beetle, Ips duplicatus (Sahlberg). Norw J Entomol 22:67-69.

Bakke A (1985). Deploying pheromone-baited traps for monitoring Ips typographus populations. Zeitschrift für Angewandte Entomologie 99:33-39.

Blaženec M, Jakuš R (2009). Effect of (+)-limonene and 1-methoxy-2-propanol on Ips typographus response to pheromone blends. J For Res 20:37-44.

Blomquist GJ, Figueroa-Teran R, Aw M, Song M, Gorzalsky A, Abbott NL, Chang E, Tittiger C (2010). Pheromone production in bark beetles. Insect Biochem Molec Biol 40:699-712.

Byers JA, Schlyter F, Birgersson G, Francke W (1990). E-myrcenol in Ips duplicatus: An aggregation pheromone component new for bark beetles. Experientia 45:1209-
1211.

Byers JA, Zhan QH, Birgersson G (2000). Strategies of a bark beetle, Pityogenes bidentatus, in a olfactory landscape. Naturwissenschaften 87:503-507.

Chararas C (1959). L'attractivité exerceé par les conifères a l'égard des scolytides et le role des substances terpéniques extraites des olésinés. In Revue de pathologie végétale et l'entomologie agricole de France, Tomd XXXVIII:113-129.

DAISIE (2009). Handbook of Alien Species in Europe. Springer, Dordrecht, $399 \mathrm{p}$.

Duduman ML, Isaia G, Olenici N (2011). Ips duplicatus (Sahlberg) (Coleoptera: Curculionidae, Scolytinae) distribution in Romania-preliminary results. Bull Transilv Univ Braşov, Series II Forest Wood Ind, Agric Food Engineer 4/53(2):19-27.

Erbilgin N, Krokene P, Kvamme T, Christiansen E (2007). A host monoterpene influences Ips typographus (Coleoptera: Curculionidae, Scolytinae) responses to its aggregation pheromone. Agric For Entomol 9:135-140.

Faccoli M, Buffo E (2004). Seasonal variability of sex-ratio in Ips typographus (L.) pheromone traps in a multivoltine population in the Southern Alps. J Pest Sci 77:123-129.

Hietz P, Baier P, Offenthaler I, Führer E, Rosner S, Richter H (2005). The temperatures, volatile organic emissions and primary attraction of bark beetles. Phyton (Austria) Special issue: „D. Grill” 45(3):341-354.

Holuša J, Zahradnik P, Knížek M, Drápela K (2003). Seasonal flight activity of the double-spined spruce bark beetle Ips duplicatus (Coleoptera, Curculionidae, Scolytinae) in Silesia (Czech Republic). Biol, Bratislava 58:935-941.

Lobinger G (1994). Die Lufttemperatur als limitierender Faktor für die Schwärmaktivität zweier rindenbrütender Fichtenborkenkäferarten, Ips typographus L. und Pityogenes chalcographus L. (Col., Scolytidae). Anz Schädlingskde, Pflanzenschutz, Umweltschutz 67:14-18.

Lobinger G (1996). Variations in sex ratio during an outbreak of Ips typographus (Col., Scolytidae) in Southen Bavaria. Anz Schädlingskde, Pfanzenschutz, Umweltschutz 69:51-53.

Martin D, Tholl D, Gershenzon J, Bohlmann J (2002). Methyl jasmonate induces traumatic resin ducts, terpenoid resin biosynthesis, and terpenoid accumulation in developing xylem of Norway spruce stems. Plant Physiol 129:1-16.

Moeck HA (1970). Ethanol as a primary attractant for the ambrosia beetle Trypodendron lineatum (Coleoptera: Scolytidae). Can Entomol 102:173-179.

Moeck HA (1978). Field test for the primary attraction of the spruce beetle. Environ Can For Serv Bi-mon Res Notes 34:8.

Olenici N, Duduman ML, Olenici V (2007). Inhibitory effect of (-)alpha-pinene high release rates on Ips typographus (L.) response to its aggregation pheromone. Analele ICAS 50:203-2012.

Olenici N, Duduman ML, Tulbure C, Rotariu C (2009). 
Ips duplicatus (Coleoptera, Curculionidae, Scolytinae)-an important insect pest of Norway spruce planted outside its natural range. Revista Pădurilor 124(1):17-24. (in Romanian)

Olenici N, Duduman ML, Olenici V, Bouriaud O, Tomescu R, Rotariu C (2011). The First Outbreak of Ips duplicatus in Romania, p. 135-140. In: Delb H, Pontuali S (Eds.). Biotic Risks and Climate Change in Forests. Proceedings of the Working Party 7.03.10 Methodology of Forest Insect and Disease Survey in Central Europe, $10^{\text {th }}$ Workshop, September 20-23, 2010, Freiburg, Germany, Berichte Freiburger Forstliche Forschung Heft, FVA.

Pfeffer A (1995). Zentral- und westpalä-arktische Borkenund Kernkäfer (Coleoptera:Scolytidae, Platypididae). Pro Entomologia, c/o Natur-historisches. Basel, Switzerland: Museum Basel 310 p.

Phillips TW, Wilkening AJ, Atkinson TH, Nation JL, Wilkinson RC, Foltz JL (1988). Synergism of turpentine and ethanol as attractants for certain pine-infesting beetles (Coleoptera). Environ Entomol 17:456-462.

Rudinsky JA (1962). Ecology of Scolytidae. Annu Rev Entomol 7:327-348.

Rudinsky JA, Novák V, Švihra P (1971). Attraction of the Bark beetle Ips typographus L. to terpenes and male-produced pheromone. Zeitschrift für agewandte Entomologie 67:179 188.
Sauvard D, Branco M, Lakatos F, Faccoli M, Kirkendall LR (2010). Weevils and Bark Beetles (Coleoptera, Curculionoidea), Chapter 8.2. In: Roques A et al. (Eds.). Alien terrestrial arthropods of Europe. BioRisk 4(1)219266.

Schlyter F, Svensson M, Zhang Q, Knízek M, Krokene P, Ivarsson P, Birgersson G (2001). A model for peak and width of signalling windows: Ips duplicatus and Chilo partellus pheromone component proportions-does response have a wider window than production? J Chem Ecol 27(7):14811511.

Schroeder LM, Lindelöw A (1989). Attraction of scolytids and associated beetles by different absolute amounts and proportions of $\alpha$-pinene and ethanol. J Chem Ecol 15:807816.

Turcani M, Csoka G, Grodzki W, Zahradnik P (2001). Recent invasions of exotic forest insects in Eastern Central Europe. IUFRO World Series, Vienna (AT) 11:99-106.

Wood DL (1982). The role of pheromones, kairomones and allomones in the host selection and colonization behaviour of bark beetles. Ann Rev Entomol 27:411-446.

Zar JH (2010). Biostatistical Analysis - $5^{\text {th }}$ edition. Pearson Prentice Hall, New Jersy, USA, 944 p.

Zúbrik M, Kunca A, Turčani M, Vakula J, Leontovyc R (2006). Invasive and quarantine pests in forests in Slovakia. EPPO Bulletin 36:402-408. 